\title{
SHAKESPEARE'S ILL WILL AND THE STYLE OF CONSENSUS
}

\author{
BY VICTOR LENTHE
}

Like many Shakespearean comedies, Twelfth Night, or, What You Will ends in a scene of general agreement. Onlookers vocalize their approval of three impending marriages, and also of the social harmony they promise to restore in the fictional Dukedom of Illyria. In waxing poetic about how "a solemn combination shall be made / Of our dear souls," Duke Orsino paraphrases the etymological root of our modern word consensus, the Latin consentire, meaning approximately thinking or feeling together. ${ }^{1}$ Yet one character is spectacularly excluded-Malvolio, the Countess Olivia's comically uptight steward, whose Italianate name my title translates as Ill Will. In an elaborate prank constituting the action of the subplot, his fellow servant Maria counterfeits a love letter encouraging him to entertain a fantasy of marrying their employer, the Countess. This misplaced hope of landing at the center of the play's marriage plot makes him appear mentally ill, leading to his confinement in a dark room, where he is tormented by a clown disguised as an exorcist.

There are as many things to say about the cruelty as there are about the hilarity. Yet the episode also touches a political nerve. In planning her prank, Maria disparages Malvolio as "sometimes . . . a kind of Puritan," in reference to the religious minority whose austere moralism he evokes when he scolds her for cavorting with three boisterous late-night drinkers (2.3.136). Even as the qualifiers "sometimes" and "kind of" counsel caution, Brian Walsh rightly notes that "discourses of Puritanism hover insistently" around Malvolio. ${ }^{2}$ This article shows two things. First, some late sixteenth-century discourses surrounding Puritanism theorized consensus in ways that give them more significance within the history of political thought than is generally recognized. Second, Twelfth Night-first performed around 1601dramatizes those debates in ways that suggest an original contribution to early modern efforts to theorize an immensely problematic concept that continues to occupy political theorists today.

William Shakespeare differs from the more overtly philosophical writers who have theorized consensus over the centuries in approaching 
it not as a logical or political challenge but as a stylistic one. Style can mean many things, but I use the term in the sense developed by Roland Barthes, who defines it as the performance of a script that in turn changes the script by repeating it with a difference. ${ }^{3}$ Applied to Twelfth Night, this means that the play lifts motifs-sometimes even verbatim passages - from religious controversies theorizing collective agreement and that it explores how their meaning changes with each iteration and in each new context. As I will show, the play makes an original contribution to those debates by recognizing that the consensus they theorize exists only in an endless series of approximations, all recognizable as iterations of each other, but none definitive. In doing so, I establish both Elizabethan ecclesiological controversies and their theatrical representation as part of the history of consensus politics, a term today associated with Jürgen Habermas and his followers, who believe that a government's legitimacy derives from the collective consent of citizens. ${ }^{4}$ I identify an overlooked parallel between this Habermasian thesis and the Puritan belief that the legitimacy of church government depends on the collective consent of church members. My hope is that early modern perspectives will provide more than a genealogy of a modern theoretical framework. All theories of consensus politics-Puritan as well as Habermasian-must confront the fact that appealing to what people in general agree marginalizes those who disagree. My above description of Twelfth Night's ending as a scene of consensus, for example, makes Malvolio's exclusion all the more bitter by suggesting that his dissent is negligible. Habermasians have answers to such problems, as did Puritans, but their solutions remain provisional. Shakespeare's interrogation of the style of consensus contributes a useful term to a theoretical framework mired in provisional solutions, because style-changing with each iteration-is openly provisional.

In reconstructing Shakespeare's ideas about consensus politics, existing scholarship is most relevant indirectly. Though consensus may prompt intuitive associations with other political concepts Shakespeare wrote about, it is not the same as toleration, inclusiveness, or popularity; other studies have focused on those. ${ }^{5}$ Consensus refers specifically to collective consent or agreement. Oliver Arnold rightly identifies its elusiveness as one factor undermining the systems of parliamentary representation he finds Shakespeare's Roman tragedies critiquing. ${ }^{6}$ Yet consensus also poses conceptual challenges in its own right, and many of them pervade the Elizabethan debates about Puritanism Twelfth Night represents onstage. In what follows, the first section reads the play's treatment of Malvolio as commenting in general terms on the 
limits of collective agreement. Next, two sections contextualize this literary-critical interpretation by showing that the play lifts motifs and phrases from debates between Puritans and anti-Puritans about the meaning and value of consensus. A fourth section infers from Twelfth Night an original contribution to those early modern debates, whereas a fifth outlines how this contribution may prove useful also to modern theorists, who are repeating the arguments of Elizabethan Puritans more than they probably realize.

\section{THE YOU OF WHAT YOU WILL}

I read Twelfth Night as promising its audience collective consent or agreement while also acknowledging that it cannot keep this promise. In doing so, I am influenced by a critical tradition reaching back to C. L. Barber, who found in Twelfth Night "a sense of solidarity about pleasure."7 For Barber, Malvolio's exclusion is justified retribution for his Puritanical opposition to the collective pleasure of others. By contrast, Donna Hamilton and Walsh take a more sympathetic view of Puritanism and construe the play as critiquing the cruelty of Malvolio's tormenters. ${ }^{8}$ Addressing the same problem from a different character's vantage point, Valerie Traub suggests that the supposedly collective pleasure of marriage plots such as Twelfth Night's will tend toward cruelty in heteronormative societies. ${ }^{9}$ James Bednarz contextualizes the play's ambivalence about collective pleasure within the so-called Poets' War, showing that it concedes Ben Jonson's moralistic critique of romantic comedy while nonetheless reveling in the evils of that crowd-pleasing genre and making a few satirical swipes at Jonson in the process. ${ }^{10}$ Such revisions of Barber's solidarity-in-pleasure thesis suggest that the play signals recognition that any solidarity its characters, readers, or spectators may find in pleasure will be exclusionary and biased toward in-groups such as non-Puritans, opposite-sex couples, and (for Bednarz) everyone who is not Ben Jonson. I that Twelfth Night is self-critical about its promise of collective pleasure or desire or love. Yet I want to highlight another facet of its conception of collective life.

The subtitle's promise to give its audience what it wills hinges more on a notion of consensus than is generally recognized. Insofar as consensus is typically thought to be a rational commitment, it differs from the collective pleasure and desire Barber and Traub find in Twelfth Night. It is analogous, however, insofar as it designates a collective experience unlikely to extend to everyone. Moreover, the wording of the subtitle_- what you will"-reflects a worldview in 
which desire overlaps with consent. The phrase can be glossed to mean what you want, thus promising a play that will please the audience. Yet such a gloss does not exhaust the subtitle's meaning. The verb "to will" had a broad range of meanings. According to the Oxford English Dictionary, its early modern usage encompassed also to be willing, to intend, to express "voluntary action or conscious intention," to affirm, to assert, or "to set the mind with conscious intention." "Such ideas resonate with modern notions of consent. To be willing is virtually a synonym, whereas the meanings denoting voluntary action reflect the common modern notion that meaningful consent is given freely and upon rational consideration. The noun form, will, was similarly flexible, encompassing certainly desire, but also intention, determination, and even (literally) "consent."12 One of the Puritans I discuss below thus defines consensus as "[t]he will of many."13 I will return to Twelfth Night's intertextual engagement with such debates about Puritanism and collective agreement. For now, I note merely that the collective life promised by the subtitle involves-besides pleasure, desire, and love-also a notion of consent or agreement. This is not, of course, to suggest that the play delivers what its subtitle promises.

The play's persistent attention to the experiences of characters excluded from the you that is supposedly getting what it wills implies a cogent critique of collectivity, including of the collective consent or agreement entailed in the promise of what you will. Yet the play, in my reading, is doubly critical. It highlights, I want to suggest, at once the insufficiency of its subtitle's promise and the impossibility of abandoning it. My interpretation thus has two components. On the one hand, I will show, the ironic ring a promise of what you will acquires in light of the play's transparently exclusionary ending highlights shortcomings inherent in any notion of collective will. Yet on the other hand, as I will also show, the play emphasizes the difficulty of avoiding some notion of what people in general want, will, affirm, or agree.

The play subverts its promise of general agreement in many ways, but the most spectacular is Malvolio's cruel treatment. Certainly he never consented to or willingly affirmed any rules stipulating his imprisonment for accepting what he reasonably believed to be his employer's sexual advances, or for wearing the yellow stockings and cross garters he thought she had asked him to wear. Even after his release, the other characters heap insult upon this injury. Olivia's initial promise, that "Thou shalt be both the plaintiff and the judge / Of thine own cause," goes unfulfilled (5.1.348-49). Fabian intercedes with the excuse that Toby and Maria had such a good time abusing Malvolio that 
they married. Since the episode integrated those two characters into the harmonious ending, he reasons, it "May rather pluck on laughter than revenge" (5.1.360). Nor is this the only case in which Malvolio is denied justice. Also in act 5, we learn that the captain with whom Viola left her women's clothes has been imprisoned "at Malvolio's suit" (5.1.272). (She had previously changed her costume to enter Duke Orsino's service disguised as a eunuch.) Without asking about the legitimacy of the case against the captain, Olivia announces matterof-factly that Malvolio "shall enlarge him" so that Viola may retrieve her gender-conforming clothes, marry Orsino, and secure the happy resolution most-but not all—characters want (5.1.274). Walsh notes that Olivia nonetheless expresses sympathy for Malvolio, but, even so, she neither redresses his grievances nor gives anything resembling an adequate reason for failing to do so. ${ }^{14}$ In her failure to give reasons she briefly resembles Sir Andrew, who previously acknowledged that he lacked any "exquisite reason" to beat Puritans and yet maintained that this was "reason good enough" (2.3.140-41). The reason Malvolio is denied justice seems to be simply that his desires stand in the way of arbitrary preferences - against the Puritanism ascribed to him, in favor of certain marriages but not others-that the other characters happen to share.

I focus on Malvolio, but other exclusions also abound and similarly call into question the definition of this you that is allegedly getting what it wills. Traub highlights Antonio, who must suffer heartbreak when he recognizes that Sebastian, to whom he had given "My love, without retention or restraint," has fallen in love with Olivia in the course of a few hours (5.1.77). Then, there is Sir Andrew, who (in a vague parallel to Malvolio) was convinced he would win Olivia's heart by challenging Sebastian to a duel, but instead receives "a bloody coxcomb" (5.1.185). These exclusions are not morally equivalent. Readers may feel bad for Antonio, because his love is sincere and selfless. They are unlikely to feel bad for Sir Andrew, who receives no more hurt than he intended to inflict on Sebastian. Malvolio's exclusion is exceptionally cruel, butfollowing readings such as Barber's - arguably in part deserved. Despite their differences, however, all three exclusions subvert the general agreement promised by the subtitle. Exclusion from a marriage plot may not be directly political, but it does raise a conceptual problem that has concerned many political theorists by highlighting that claims to represent a general or collective will usually privilege some people's wills over others. Transposing this fundamental problem of political theory to the rose-tinted world of romantic comedy is less substantive 
a difference than it might at first appear. Already Aristotle theorized the polis by analogy to the oikos.

Yet there is a paradox. Notwithstanding Twelfth Night's sweeping critique of collective will, the play does not exactly reject the idea either. Malvolio's story, for one, cuts both ways. The most vocal dissenter in the final scene, he storms out vowing to "be revenged on the whole pack of you" - that is, on the architects of a societal consensus that excludes him (5.1.371). Yet understandable as his reaction may be, it would be incongruous to read the play as inviting too much sympathy for it. Just as Sir Andrew receives the same injuries he intended to inflict on Sebastian, so Malvolio would eagerly impose his own exclusionary consensus on others if given the chance. Bednarz notes that Malvolio shares many of the same vices as the characters to whom he falls victim, highlighting especially their propensity to self-love. ${ }^{15}$ Attempting to pass off one's preferences as though they represented a general consensus must be the epitome of such egoism. Witness the terms in which Malvolio scolds four drinkers making noise in the kitchen late at night:

\begin{abstract}
My masters, are you mad or what are you? Have you no wit, manners nor honesty but to gabble like tinkers at this time of night? Do ye make an alehouse of my lady's house that ye squeak out your coziers' catches without any mitigation or remorse of voice? Is there no respect of place, persons nor time in you?
\end{abstract}

The speech invokes a notion of normative behavior resembling the one to which Malvolio later falls victim himself. His suggestion that failing to abide by his rules is tantamount to "mad[ness]" implies that debate is superfluous, because all reasonable people already agree. Likewise, his suggestion that dissent from these norms amounts to having "no wit, manners nor honesty" signals his belief that submission to his preferences is a condition for membership in society. Such eagerness to exclude others discredits Malvolio's subsequent outrage about his own exclusion.

Elsewhere too, Malvolio behaves in ways that undermine any ethical force his antagonistic final gesture might otherwise have. Much of Maria's and Toby's prank consists in watching him fantasize about a resolution to the play's marriage plot that would be as exclusionary as the one to which he is ultimately subjected. Believing that Olivia will marry him, he dreams aloud-for most of act 2, scene 5-about the power this will bring him: he will wear a nice velvet gown and expensive 
jewels, make Toby stop drinking, and insult "foolish knight[s]" like Sir Andrew whenever they annoy him (2.5.76). Toward his fellow servants, he actually begins to adopt this arrogant demeanor, telling them at one point, "Go off, I discard you. Let me enjoy my private" (3.4.86-87). Yet his fantasies of antagonizing his own subsequent chief-antagonizer, Sir Toby, may do the most to reveal his hypocrisy. When he dreams that he "will baffle Sir Toby" (2.5.157-58), he even uses the same word Olivia subsequently applies to the cruel trick Toby has played on him: "Alas, poor fool, how have they baffled thee," she sympathizes with him in the final scene (5.1.363). Malvolio's wished-for ending, in other words, is just as exclusionary as the real ending he subsequently critiques. The only difference is that in his fantasy it is the others who are excluded-hardly an indication of moral credibility.

Malvolio also fails, just as spectacularly as anyone else, to give reasons for his transparently exclusionary preferences. In a moment of dramatic irony, he takes pains to deny that this fantasy is the type of purely subjective preference that it of course is. "I do not now fool myself to let imagination jade me," he says, "for every reason excites to this, that my lady loves me" (2.5.159-61). In fact, as is obvious to any spectator or reader who has watched the plot unfold, Malvolio's conclusions have nothing to do with reason, and everything with imagination, understood in the most disparaging sense of the word as a personal desire with no legitimate bearing on collective life. Maria's counterfeit love letter may have invited him to indulge in these fantasies, but it was addressed only to a mysterious "M.O.A.I." and signed, anonymously, "The Fortunate Unhappy" (2.5.106, 155). Malvolio's assumption that Olivia wrote these words to him reflects nothing if not his unreasoned, arbitrary wish. His notion that it has anything to do with reason is as ridiculous as Sir Andrew's previous protestation (already quoted above) that any reason is good enough to beat a Puritan. Such moments expose the most vehement critic of the play's what-you-will ending will as a hypocrite.

Appealing to what people in general will or agree tends to avail itself of a self-serving logic. This observation will be intuitive to many modern political theorists, but Twelfth Night brings it to life. ${ }^{16}$ Multiple characters in the play advance notions of social harmony they insist are self-evident. Malvolio asserts that his enemies are mad, while they, in turn, submit him to an exorcist to cure his own supposed mental illness. Fabian insists that anybody would feel so happy for the newly married Toby and Maria as to excuse the harm they did Malvolio, whereas Malvolio suggests it would be obvious to anyone that Olivia 
loves him, and Sir Andrew that the reasons for beating Puritans are similarly self-evident. Actually, of course, none of these positions are self-evident. By invoking consensus without actually persuading everyone, and by continuously failing to give reasons, Twelfth Night's characters misrepresent their various, mutually contradictory, and largely arbitrary preferences as matters of general agreement. Yet their conviction in doing so also signals how difficult it can be to get away from the inherently problematic notion of consensus.

Though the play highlights the shortcomings of consensus, that is, it also suggests that there may be no alternative-that Malvolio, for example, is just less effective in his use of a rhetorical device everyone invariably uses in conceptualizing public life. The final two sections of this article will discuss the solution Twelfth Night proposes to this social and political problem. Yet in order to give its solution specificity I first contextualize the play's conflicted assessment of collective will within a sprawling, decades-long debate about Puritanism.

\section{PLACE AND TIME FOR MALVOLIO}

Along with Measure for Measure's precise Angelo, Malvolio is one of two stage Puritans in the Shakespeare corpus and the only one explicitly called "Puritan." ${ }^{17}$ He evokes the austere moralism widely ascribed to Puritans by preventing a boisterous late-night drinking party in act 2 , scene 3 and in causing trouble for Fabian "about a bear-baiting" (2.5.7). He evokes the dubious scriptural hermeneutics Puritans' opponents ascribed to them when he wishfully misconstrues the anonymous (and counterfeit) love letter as being addressed to him. He evokes Puritans' empahsis on predestination with such lines as, "it is Jove's doing and Jove make me thankful!” (3.4.72-73). Such connections to Puritanism are amply highlighted in criticism about the play. J. L. Simmons notes that Malvolio's "heavily emphasized gratitude clashes oddly with [his] conceit[edness] unless the contradiction is seen in the context of late Elizabethan Puritanism." ${ }^{18}$ Even in a comedy that otherwise revolves around love and laughter, the specter of Puritanism provides an overtly political reference point. As I show in a subsequent section, Puritan political theory was more focused on consensus than is generally recognized. Yet in order to understand Shakespeare's commentary on that issue, I begin by clarifying Malvolio's relationship to the religious and political movement associated with Thomas Cartwright, Dudley Fenner, and others like them. 
Malvolio's Puritanism poses an interpretive crux. Partly this is because Puritan, as a label, is inherently fuzzy. It designates English Protestants dissatisfied with the national church government, but the nature of their dissatisfaction varied widely. Historians such as Patrick Collinson and Lori Anne Ferrell have therefore suggested that perhaps the only truly unifying feature of Puritans was that people in the good graces of the church establishment attached the epithet to them. ${ }^{19}$ Maria's accusation of Puritanism therefore carries special weight. Collinson himself also classifies Malvolio as a stage Puritan. ${ }^{20}$ Still, other questions remain. Simmons interprets Malvolio as a satirical parody of Puritanism, and Phebe Jensen establishes Shakespeare's attachment to pre-Reformation traditions of festivity as a plausible motive for such anti-Puritan animus. ${ }^{21}$ By contrast, Hamilton contends that the play satirizes the cruelty of Malvolio's anti-Puritan enemies. ${ }^{22}$ Jeffrey Knapp argues, somewhat against all three, that it actually satirizes an excessive zeal shared by Puritans and their detractors. ${ }^{23}$ Paul Yachnin warns against overstating Malvolio's resemblance to "real-life Puritans," but allows that several obvious points of similarity serve to make the steward's other vices hateful. ${ }^{24}$ Walsh, by contrast, submits that Twelfth Night shows sympathy both for Malvolio and for his enemies, and that Shakespeare is less concerned with satirical fault-finding than others have supposed. ${ }^{25}$ I propose a different possibility: Twelfth Night indeed contains hard-hitting religious satire, but it targets neither (pace Simmons) Puritans nor (pace Hamilton) anti-Puritans. Rather, as I begin by showing, Twelfth Night ridicules a series of debates about Puritanism. In doing so, I link the play to the comprehensive political theories controversialists proposed in the process of rationalizing their positions on the Puritan question.

Existing scholarship partially acknowledges my distinction between Puritans and the debates about them. One of Simmons's most intriguing findings is that Malvolio's enemies describe him in terms lifted verbatim from anti-Puritan tracts. In describing Malvolio's speech as "bibble babble" (4.2.97) and in ridiculing his "singularity" (2.5.148), for example, his enemies use words Richard Bancroft, John Aylmer, and the anti-Martinist writers applied to their Puritan opponents. Further, the name of Malvolio's antagonist Sir Toby Belch evokes one Sir Toby Bland, author of a 1589 anti-Puritan tract. ${ }^{26}$ Such echoes suggest both that Malvolio was legible as a stereotype of Puritanism and-more importantly for me-that real-life debates about this religious movement were part of the play's immediate frame of reference. 
Compelling as Simmons's evidence is, however, his article misses an essential point. My own review of the play's intertextuality reveals that Malvolio in fact reflects Puritans' stereotypes of their enemies as much as their enemies' stereotypes of them. Take his speech chastising Toby, Andrew, Feste, and Maria for their late-night partying - the grumpy lecture initially prompting Maria to call him a Puritan. Above I discussed the full speech, with its appeal to norms that everybody would supposedly agree to. Here I return to the final line: "Is there no respect of place, persons nor time in you" (2.3.89-90)? A critical commonplace has long misidentified this phrase as an allusion to the dramatic unities of place, time, and action promoted by such early modern literary theorists as George Puttenham. Shakespeare's rival playwright Jonson had indeed recently faulted him for breaking these rules, so putting the phrase in Malvolio's mouth may have had the effect of suggesting that only a killjoy could care about such things. ${ }^{27}$ That interpretation, however, faces one important obstacle: Malvolio never invokes the third unity - action-and instead refers to a respect for persons with no apparent connection to early modern dramatic theory.

A different intertextual reference appears more plausible: the appeal to place, persons, and time was a refrain in Elizabethan debates about Puritanism. The three terms were a common stand-in for a larger category of issues known as things indifferent-things left unregulated by Scripture, such as liturgy and ecclesiology. In the so-called Admonition controversy of the 1570 s, the prominent antiPuritan John Whitgift asserted that the national church was justified in legislating such things indifferent with "consideration to the tyme, place, persons, and other such circumstances." ${ }^{\text {"2s }}$ Whitgift meant, for example, that the national church could legislate the way sacraments such as baptism were to be performed. Scripture was vague on these points, but Whitgift nonetheless held that the ceremonies were only valid if conducted in the manner stipulated by church authorities. For baptism, for example, the proper time was infancy, the proper the place a church, and the proper person an ordained minister. Such stipulations were an affront to Puritans, because they believed such decisions should either be made locally, by parish elders, or left up to individual conscience. The Puritan Thomas Cartwright emphasized that he was not objecting to Whitgift's particular legislation of persons, place, and time, but rather to the notion that such things could be legislated at the national level. ${ }^{29}$ I will return below to Whitgift's umbrella term "circumstances," which captures a whole host of other liturgical and ceremonial expectations, but the controversy over "tyme, place, [and] 
persons" clearly offers a more complete pattern for Malvolio's speech than do the neoclassical unities of time, place, and action.

By 1601, appeals to place, persons, and time had become so firmly ensconced in anti-Puritan discourse that Twelfth Night's allusion would have been recognizable. In 1584 Richard Cosin contended that ecclesiological matters "may be altered and changed, as shall be thought expedient" by Church of England authorities "vpon circumstances of times, persons and places." ${ }^{30}$ Richard Harvey's 1590 refutation of the pro-Puritan Marprelate tracts included a long meditation on the "three circumstances" of the sacrament of baptism: "the time when, the place where, and the persons by whom." 31 Also in 1590 George Gifford (a moderate Puritan who however took the establishment's side in this particular controversy) defended the national church's authority to regulate ceremonial issues. Scripture, he contended, provided "generall rules," but it was up to bishops and other high-ranking church officials to modify them "for circumstances of time, place, persons, sitting, kneeling, \&c."32 In 1597 Richard Hooker reworked the anti-Puritan argument, granting that God generally left us "at our owne choice, both for time, and place, and forme" of things indifferent, but also insisting that "members of a publique body" forfeit this choice. ${ }^{33}$ Especially laymen, Hooker writes, must abide by authorities' judgments about things indifferent "when the state of time, or place, or person thereunto compelleth." 34 As the reader will see, the precise wording can vary, but the triad of persons, place, and time was a common synecdochic reference to the larger category of things indifferent, whose regulation pro-establishment, anti-Puritan writers such as Cosin and Hooker placed in the hands of the national church government.

Puritans, in turn, vehemently rejected the authority their opponents claimed over the persons, places, and times of religious life. The Brownist Henry Barrow thus opined in response to Gifford that God had left "matters of place, time, and such circumstance" unlegislatable, "knowing there woulde bee no end of such perticular lawes" once a government body started making self-serving pronouncements. ${ }^{35}$ This was also Fenner's critique of Cosin. Harnessing stereotypes of the Roman Catholic Church as self-servingly authoritarian, Fenner complained that it "casteth a strong s[c]ent of the Romishe practize" when authorities legislate sacraments" "circumstances of time, number, persons, and such like."36 Andrew Willet, responding to Hooker, similarly claimed to be "at our wittes ende" as to the importance his opponent attached to episcopal stipulations about "the place, the time, or some such like circumstance" of baptism. ${ }^{37}$ According to these 
Puritan writers, the national church government had no legitimate role in controlling the exact manner in which people received baptism or communion, or how they conducted worship. If the place, time, and persons of such ceremonies were not stipulated by Scripture, they contended, then they must be left up either to parish elders or individual conscience.

But back to Twelfth Night. Malvolio's exhortation to "respect . . . place, persons [and] time" adds a wrinkle to his stage-Puritanism, because his enemies label him a Puritan at the precise moment when he begins echoing anti-Puritans' insistence on their right to legislate exactly those three things (2.3.90). The steward may well evoke establishment stereotypes about Puritans, as Simmons, Hamilton, and Walsh highlight in different ways. Yet his desire to control the respect due to persons, place, and time also reflects, vice-versa, Puritans' stereotypes about their establishment opponents. Such even-handedness may contribute to the sense of tolerance Walsh and Knapp find in Twelfth Night's representation of Puritanism..$^{38}$ Yet the specificity of Malvolio's textual echo suggests, further, that Twelfth Night's satire targets anti-Puritan controversies as a field of debate, rather than any of the groups participating in them. Moreover, as I show in the next section, the particular debate about place, persons, and time was one area where Puritan and anti-Puritan writers were most industrious in articulating new conceptions of collective agreement.

\section{HABERMAS AMONG THE PURITANS}

The persons of religious life were the most politicized item in the list of things indifferent debated by Puritans and their opponents. The persons in question were normally clergy, and thus the local representatives of the Church of England's government. One point of contention was whether bishops had free sway in appointing them (as the establishment held), or whether (as Puritans countered) they needed first to secure the consent of the parishes these ministers were to lead. The debate about these persons or parsons (as the word was interchangeably spelled in 1601) thus hinged on the role of collective consent or consensus in legitimating governmental structures. ${ }^{39}$ This conceptual node deserves to be mapped more fully than it is in existing scholarship. Whereas historians such as Peter Lake address various aspects of Puritans' ideas about political consent, I trace their efforts to extrapolate from consent tout court to the collective agreement today more typically rendered as consensus. ${ }^{40}$ Even as existing 
scholarship sometimes uses consensus as an analytic category, it rarely addresses how early modern writers used the word or expressed the concept. ${ }^{41}$ However, I find in arguments about persons, place, and time a history of how the English language expresses the concept of collective agreement and establish this as a cultural reference point for the "sometimes," "kind of" stage Puritan haunting Twelfth Night's allegedly what-you-will ending (2.3.136).

Consensus was originally the Latin word for consent. Because it appears throughout the canons regulating church government, Reformation controversialists devoted considerable effort to redefining it. ${ }^{42}$ A particular flashpoint were canonical stipulations that clergy be appointed by the consent of church members- "consensu clericorum et laicorum," as one council had worded it. ${ }^{43}$ There were different ways to construe such stipulations. For one, the Act of Supremacy had called into question whose consent counted-Christendom's, or merely England's? Even beyond this, historians of the period highlight that consent itself could be construed variously. ${ }^{44}$ Yet part of the challenge was to conceptualize consent as a collective phenomenon encompassing all church members, however one might define either membership or consent. This gave Puritans polemical leverage. Insofar as they dissented (and almost by definition they did), they could claim that the national church failed to live up to the consensus standard of legitimation stipulated by canon law.

One tract faulting the higher church authorities for this was An Abstract of Certain Acts of Parliament, probably written by William Stoughton and published (probably by Robert Waldegrave) around $1583 .{ }^{45}$ Its critique is wide-ranging, but its most specific target are people it calls Nonsidents, a neologism specially coined to disparage non-resident ministers. Common practice allowed ministers to collect salaries for nominal duties in provincial parishes, while they in fact lived in London and hired underlings to do their weekly preaching. These were the persons of the persons, place, and time refrain in the debates discussed above.

Stoughton's critique of these persons turns on the question of collective consent. A "person Nonsident," he argues, operates "without consent of the people." ${ }^{6}$ Though consent as such had long been a wedge issue in ecclesiological debates, Stoughton's concern is, more specifically, with the relationship between individual and collective consent. He glosses the relevant church canons with care, emphasizing that the "consensus" they stipulate entails a particular type of "consent or approbation" understood to be "[t]he will of many, vnto 
whom, the matter apperttayneth, ioyntly linked togeather." ${ }^{\text {47 }}$ Though a lexicographer may categorize the word as a quotation from Latin, Stoughton uses consensus more like a Latinism than like a genuinely foreign word. ${ }^{48}$ His extensive gloss plainly offers more than a simple translation, which he could have given in the single word consent. By leaving will in the singular and by suggesting people are linked together as though they constituted one single body, he emphasizes that the particular type of consent designated by consensus is collective. Stoughton is vaguer on the question of who is included in this collective decision-making process. He specifies that the many to be consulted should be people affected by the decision, but offers no numerical definition of "many." This combination of specificity and vagueness had radical implications. One contemporary understood him to mean that a minister's appointment was not legitimate "till euerie one ... doo agrée vnto the election." 49 The quotation is from a detractor about whom I have more to say below. Nonetheless, in absence of any clear specification to the contrary, his construction of Stoughton's words is as reasonable as any: the consensus at stake was the collective will of everyone affected by an issue.

It is worth pausing to emphasize the degree to which Stoughton's relevance as a thinker extends beyond his historical moment. His argument about consensual legitimation is intriguingly similar to one followers of Habermas make today. For them, a government is legitimate only insofar as it remains responsive to the consensus of the public it governs. ${ }^{50}$ Political legitimacy thus hinges on an "in der politischen Offentlichkeit kommunikativ erzielten Konsens"- on a consensus achieved by means of communication in the political public sphere.$^{51}$ Even as the other term in that quotation-public sphere, or Offentlichkeit - is increasingly a fixture in scholarship on Shakespeare's England, early modern ideas about consensus rarely get more than a passing mention. ${ }^{52}$ Yet Stoughton is every bit as much concerned with this term as Habermasians are. His early modern usage veers back and forth between the Latinism consensus and the more traditionally English consent, but this in no way reduces his resemblance to Habermas. In Habermas's German, Konsens means both consensus and consent, and context reveals whether one is talking about consent tout court or the collective version of it that in modern English goes by the name consensus. Moreover, as I highlighted above, Stoughton's Abstract devotes considerable effort to theorizing precisely this distinction. To be sure, Stoughton is writing about a church government, Habermas about a secular, constitutional state. Yet within their respective areas of 
concern, consensus is central to each thinker's conception of governmental legitimacy, which (for both) requires the collective consent or consensus of the governed.

Stoughton also resembles Habermas in his definition of what counts as genuine consensus. Compare, for example, his standard of including everyone affected by an issue to Ciaran Cronin and Pablo de Greiff's paraphrase of Habermas: "Just those norms are valid to which all possibly affected persons could agree." ${ }^{.3}$ Likewise, in the words of Seyla Benhabib, the legitimacy of any given consensus requires "the equal chance of all affected to initiate [a] discourse of deliberation." ${ }^{54}$ For these Habermasians, as for Stoughton, having one's will considered in society's negotiation of consensus is a mark of citizenship, making people (here in Stoughton's words) "Citizens in deede, and in name," as well as making them "Citizens of the place," or parish, whose consent the authorities were supposed to secure. ${ }^{55}$

Even the differences between Stoughton and Habermas highlight how much their theoretical frameworks have in common. One difference is that the Abstract leaves unclear whether it envisions citizenship extending beyond property-owning men. Yet the fact that a contemporary discussed below already faulted Stoughton for failing to specify this also indicates how much his argument raised questions about inclusiveness, even if Stoughton himself failed to give adequate consideration to them. A second point of difference is that Stoughton never specifies how he envisions the formal activities of government relating to people's informal interactions in society. This distinction is essential for Habermasians, who situate the process of consensus formation within a "lifeworld" distinct from the government it legitimates. ${ }^{56}$ Yet such differences indicate merely that Stoughton had not recognized all of the challenges associated with consensus politics. More striking are the similarities between him and Habermas, making tracts such as the Abstract part of the history both of consensus politics and of English-language attempts to express the idea of collective agreement.

Stoughton's consensus politics are admirable in many ways, but Shakespeare may be the more insightful political theorist in critiquing the idea of collective will on which it rests. Some of the problems with consensus politics are historically specific, but many are logical and conceptual. By highlighting problems any appeal to consensus will raise independent of historical context, modern theoretical scholarship illuminates two philosophical challenges Puritans faced—and which Twelfth Night could exploit for satirical fodder when it lifted passages from their tracts. First, since an agreement with everyone is usually 
impossible, consensus-based legitimacy will never be more than an approximation. Virtually all modern proponents of consensus politics acknowledge this first critique and frame their theories of legitimacy, accordingly, as offering approximations of an ideal that remains forever out of reach. ${ }^{57}$ The second problem with consensus politics is more difficult to bracket. It stems from the fact that the venues in which society negotiates its consensus are often not equally accessible to everyone. In one feminist version of this critique, Nancy Fraser notes that women are more frequently interrupted in faculty meetings and that any consensus produced there will consequently be unfairly weighted in favor of male professors. ${ }^{58}$ There are two responses to this second problem, one of them reconcilable with Habermas, the other not. Fraser's own response is to continue the pursuit of consensus, but with the caveat that societies must make accommodations to ensure that the process be "inclusive and fair." 59 By contrast, agonistic pluralists such as Chantal Mouffe contend that consensus should be abandoned as a political ideal. ${ }^{60}$ There are further nuances within these debates, but the basic critique is that idealizing consensus excessively can undermine the non-coercive legitimacy it is intended to provide.

Perhaps the most illuminating aspect of modern debates about consensus are their failures. The project of conceptualizing a genuinely inclusive consensus remains unresolved and possibly irresolvable. This is not to imply that theoretical debates about this topic have not been productive in highlighting political problems and challenges, only that they rarely identify more than provisional solutions. One indication is the degree to which Habermasians have redefined their central concept. Habermas's 1981 tome Theory of Communicative Action, contended that the societal consensus legitimating the state must itself, in order to be legitimate, be negotiated in publicly comprehensible termsthus notably excluding revealed knowledge from consideration. ${ }^{61}$ Subsequently Habermas has backtracked, partly out of concern that excluding religious language might also exclude religious people. By 2006 he therefore demanded that people be allowed to use whatever language they choose to negotiate their society's consensus. ${ }^{62}$ Though responding to legitimate concerns about inclusivity, this evolution in Habermas's thought proposes the unintuitive idea of people collectively consenting to ideas articulated in language many of them cannot understand. Thus there is good reason to demand further modification, as Victoria Kahn, for example, does ${ }^{63}$ Such tinkering with the central concept of the consensus politics model has led some observers to ask whether these theoretical debates are even worthwhile. Mark Warren 
calls them "increasingly unproductive" and proposes to bracket them in favor of "pragmatic" problem-solving strategies. ${ }^{64}$

Just as Stoughton resembles Habermas in advocating for consensual legitimation, so too does he resemble him in eliciting a seemingly endless string of objections, disagreements, and demands for modification resulting in a deadlock comparable to the one Warren identifies today. Within the year, Cosin published his Answer. Above, I quoted this tract as an instance of the persons, place, and time refrain that Malvolio echoes. I now discuss its main purpose, which was to refute Stoughton's tract, including its insistence that the persons of that triad must be legitimated by the consensus of church members. Intriguingly, of the many counterarguments Cosin found, the two that would gain the most traction in the ensuing controversy stem from concerns that continue to occupy modern proponents of consensus politics-political dysfunction and exclusions. ${ }^{65}$ To emphasize the potential for dysfunction, Cosin predicts (in a passage already partially quoted above) a doomsday scenario in which Stoughton "will hereby ouerthrow all the ministerie, if they must tarrie without roomes to minister in, till euerie one ... doo agrée vnto the election. ${ }^{\prime 66}$ Cosin seems less outraged about the exclusionary tendencies of consensus politics, but he nonetheless cites them as evidence of Stoughton's theoretical shortcomings:

\begin{abstract}
Now it had béene verie requisite, that [Stoughton] for the approouing of these democraticall elections the better vnto vs, should . . . haue shewed; Whether women and children of some reasonable discretion, should haue voices in the election of their minister? Whether he should be chosen by all, by the greater part, or by the better part? Whether the wiues voice should be accompted seuerall, or but one with hir husbands, or whether she might dissent from hir husband, or the sonne from his father? Whether the patrone not dwelling in the parish shall haue a voice, or dwelling there but a single voice? Whether the greater number of voices shall be accompted in respect of all the electors, or onelie in respect of him which is to be chosen, hauing more voices for him, than any other hath? Whether all absent shall be accompted to dissent or to assent? Whether sicke men, and other necessarilie imploied, that would come and cannot, may send their proctor[. . .]?67
\end{abstract}

In faulting Stoughton for failing to address exclusions based on gender, age, disability, and class, Cosin weirdly recalls Fraser's critique of Habermas. Of course, Cosin has no apparent interest in fixing these exclusionary tendencies. He merely points out that Stoughton fails adequately to theorize the central concept of his "democraticall" politics. Yet his argument is eminently plausible in contending that 
consensus politics raises, at once, concerns about dysfunction and questions about whose consent counts.

Stoughton's allies took these critiques to heart, as evidenced by such tracts as Fenner's COVNTER-POYSON. Fenner contends that a reasonable approximation of Stoughton's ideal can indeed be functional. He explains, first of all, that Cosin was making a straw man, because the need to convince every last holdout was "neuer maintained . . . but by Anabaptistes." ${ }^{\prime 68}$ Mere Puritans such as he and Stoughton, by contrast, envisioned consensus taking shape under "the gouernment and direction of the Elders [of any given parish]," who were actually capable of reaching decisions. ${ }^{69}$ Fenner's explicit acknowledgment that expediency demands working with a mere approximation of consensus represents his main contribution to Stoughton's position. He dodges Cosin's questions about how to make the approximation fair, suggesting sheepishly that "the substantiall pointes of Church-election" may "according to the word of God ... [,] vpon diuers circumstances, be diuersly carried." ${ }^{\prime \prime 0}$ In other words, many approximations of consensus are conceivable, but such details are incidental to the theoretical principle he shares with Stoughton. The core of his admonition remains, "not to shut out the due consent of the people."

The most theoretically sophisticated Elizabethan critique of Stoughton's and Fenner's position is Hooker's magnum opus, Of the Laws of Ecclesiastical Polity, of which the preface and first four books were published in 1593. One of Hooker's great innovations was to co-opt Puritan arguments and rhetoric and to repurpose them in service of an anti-Puritan church establishment. ${ }^{72}$ On the issue of consensus, this played out as follows: whereas Cosin disputed Stoughton's claim that church government required collective consent, Hooker attempted to show that consensual legitimation was already in place. His rationale was to treat the Church of England as a "public society," a phrase that in early modern English meant the same thing as corporation. ${ }^{73}$ As Hooker writes, "the act of a public society of men done five hundred years since standeth as theirs, who presently are of the same societies, because corporations are immortal." 74 In other words, current members of a corporation are required to abide by decisions and commitments previously made by that corporation. Politically the effect was to weight the Church of England's supposed consensus in favor of pre-Reformation ancestors, but the rationale is worth spelling out, because it introduces yet another early modern term for collective agreement. A public society gives what Hooker calls "public consent." 75 
Once given, he contends, public consent remains in force no matter how many individual members of the corporation subsequently come to dissent privately.

Emerging from these Elizabethan debates about Puritanism is thus a field of discourse attempting to define consensus, but never quite succeeding in doing so. The attempt is clear: whether they use the Latinism consensus, or English cognates such as public consent or the consent of the people, these writers are talking about collective agreement. Yet the attempt is never entirely successful. First, as Cosin emphasizes, truly living up to the ideal of consensus would preempt any hope of a functioning government. Second, workable approximations of this ideal are bound to be exclusionary, as evidenced by Hooker's and Fenner's efforts to justify a supposed agreement to which their respective opponents had obviously not agreed. Today theorists propose various solutions to this conundrum. As these anti-Puritan debates show, however, Elizabethans were similarly occupied with the conceptual challenges of justifying their politics by reference to what people in general agree. Even more intriguingly for my purposes, they associated these challenges both with Puritanism and, more specifically, with attempts to regulate the times, places, and persons of religious life to which Twelfth Night's stage Puritan alludes unmistakably in his hopeless demand that a group of revelers respect "place, persons [and] time" (2.3.90).

\section{THEORIES AND STYLES OF CONSENSUS}

Twelfth Night's references to such debates about Puritans and consensual legitimation recast its ambivalent promise to give a vaguely defined you what it wills. Building on the reading of the play outlined in section one, I now reconstruct a contribution the play is making to early modern debates whose challenges Habermasians have inherited. The play's treatment of consensus differs from all the conventionally theoretical accounts discussed in this article, modern as well as early modern. No doubt its suggestion that consensus has both benefits and drawbacks represents a position widely shared by many of the modern theorists discussed above, and even its diagnosis of an impasse in people's attempts to assess these pros and cons would likely meet with approval from Warren. Yet in contrast to those theorists, Twelfth Night signals little interest in constructing sounder, more just, or more workable definitions of consensus and instead approaches the issue as a problem of style. 
The notion of style that captures what Shakespeare does with Puritanism is best articulated by Barthes, who defines it as a repetition that deviates from its model. Barthes's lead illustration is the opening line of Honoré de Balzac's novel Sarrasine, which he suggests echoes a proverb about the psychological effects of Bacchanalian excess, while also changing the normal saying by adapting it to a realist novel. $\mathrm{He}$ contends that the repetition's difference changes also the original's meaning - in other words, that Balzac's canonical status turns his quotation-with-a-difference of folk wisdom into its own kind of folk wisdom, thus adding to a French cultural heritage that will be slightly different for each such addition. Barthes's punch line must be the best gastronomical metaphor of poststructuralist theory. Style is not like an apricot, whose pit might be taken to symbolize an origin, a kernel of truth around which the rest has grown. Style is more like an onion, in which layer grows upon layer, each one slightly different but equally authentic. Nobody looks for the center of an onion. Whereas style begins with citation, it thus ultimately denies the authority of the thing cited. ${ }^{76}$

Much of the material this article has been discussing evokes Barthes's notion of style as repetition with difference. Cosin's scathing critique prompted Fenner to repeat Stoughton's argument with a difference, while Hooker-motivated to claim the attractive prospect of consensual government for his side as well-repeated their argument while redefining the consenting party in such a way as to void Stoughton's political point. ${ }^{77}$ Twelfth Night, in turn, rearranges its religiopolitical sources parodically, in a way that calls into question whether any of them make sense at all. Malvolio's self-serious imitation of a refrain from differently self-serious ecclesiological controversies represents one style of consensus. I now highlight four additional styles. Many are drawn from speeches anticipating the play's what-you-will ending, with its specious promise of what we-however one construes the pronoun's reference-collectively want, affirm, or intend. All echo a motif from anti-Puritan controversies appealing to supposedly agreed upon persons, places, and times.

For example: in anticipation of her marriage to Orsino and reunification with her lost brother Sebastian, Viola echoes Malvolio's echo of anti-Puritan debates as follows:

If nothing lets to make us happy both

But this my masculine usurped attire,

Do not embrace me till each circumstance

Of place, time, fortune do cohere and jump

(5.1.245-48) 
The speech evokes Barthes's notion of style as repetition with a difference both because its appeal to circumstances, place, and time repeats three key terms from anti-Puritan controversies and because, in doing so, Viola repeats Malvolio's earlier repetition. Like Malvolio's exhortation to peace and quiet, Viola seeks to instantiate a normative notion (surely an imperfect one) of how things should be-in her case, a marriage ceremony in a seventeenth-century notion of gender-appropriate clothing that will reintegrate her into the social order as a wife and sister, while also bringing the play to a conclusion its implied audience will like. In doing so, she appeals (like Malvolio) to rules about place and time, as well as to the circumstances that in ecclesiological debates offered a catch-all term encompassing all such things indifferent. Both Viola and Malvolio thus repeat the wording of exhortations to submit to an arbitrary consensus about circumstances, persons, place, and time, while also departing from the affective and social register of ecclesiological debates by transposing their terms from a church polity to a comedy about domestic life. At the same time, Viola differs from Malvolio. Whereas Malvolio sought to impose norms of persons, place, and time as an a priori condition of sociability, Viola instead emphasizes that such circumstances must "jump" and in other words take on a life of their own. In addition, Viola makes no explicit reference to persons, thus deemphasizing the issue tied most directly to formal government structures.

The third style I cite is Orsino's. It resembles Viola's broadly, but not in every point. Looking forward to the same what-you-will ending, Orsino similarly invokes time and place, but not persons:

When [. . .] golden time convents,

A solemn combination shall be made

Of our dear souls. Meantime, sweet sister,

We will not part from hence.

$$
(5.1 .375-78)
$$

In the introduction I suggested that two of these lines paraphrase the etymological root of consensus as thinking and feeling together. Yet the speech as a whole also offers a further variation on the persons, place, and time motif that Malvolio adopted from anti-Puritan arguments about church government. The "golden time" Orsino believes will legitimate the marriage is the time at which Viola will have recovered her women's clothing (itself a circumstance of the marriage ceremony). In waiting for this time to "convent" - a variant of convene and thus a synonym for Viola's "cohere" — he shares Viola's notion 
that the regulation of such things indifferent cannot be imposed but rather comes together naturally. ${ }^{78}$ Unlike Viola, he believes the place is settled-the one in which they are presently standing, since he says they will not depart "from hence." Again evocative of Viola's style, however, is the phrase, "A solemn combination shall be made," which in its passive voice draws attention to Orsino's neglect to specify the person, the priest or minister legitimating the marriage.

By contrast, Olivia's style of anticipating the what-you-will ending emphasizes the persons legitimating it. To contextualize her words it may be necessary to review the play's convoluted plot: she thinks she has married Cesario, the male persona Viola has invented to get close to Orsino, but in fact she has married Viola's twin brother, Sebastian. When Viola (as Cesario) expresses surprise at being claimed as someone's husband, Olivia calls the priest - the person of persons, place, and time- to testify that the marriage was properly conducted and Cesario's consent genuine and binding. The words are the priest's, but they represent Olivia's attempt to legitimate her marriage and thus her idea of the norms her society has collectively agreed to (not to mention a specific marriage she believes Cesario has individually agreed to):

A contract of eternal bond of love,

Confirmed by mutual joinder of your hands,

Attested by the holy close of lips,

Strengthened by interchangement of your rings,

And all the ceremony of this compact

Sealed in my function, by my testimony.

The speech is about marital consent, but it is equally about consensus, insofar as it addresses generally agreed upon procedures for legitimating marriages. Though the priest mentions a number of factors-including Olivia's and Cesario's consent and their participation in ceremonies such as the exchange of rings - his argument emphasizes his own role or "function" in solemnizing the marriage. It emphasizes, in other words, the persons that Viola and Orsino ignore in favor of place and time. These persons, the argument goes, rightfully regulate, legitimate, and adjudicate the procedures by which people give consent. The notion evokes Hooker's belief that he, as a member of the clergy, was specially qualified to determine that the people had technically consented even when many of them thought otherwise.

The fifth style of consensus I cite is Feste's interrogation of Malvolio in act 4, scene 2, when "Malvolio the lunatic" is imprisoned because his attempts to flirt with Olivia seemed to indicate mental 
illness (4.2.21-22). Unlike the styles discussed above, Feste neglects to propose his own notion of what you will. Instead, he punctures Malvolio's idea of what everybody has agreed to. Disguised as a priest named Sir Topas, Feste catechizes Malvolio about topics including the Pythagorean doctrine of reincarnation. Posing a question and demanding an answer that all Christians are supposed to agree with, the form of the catechism inherently appeals to consensus. As Feste makes clear, Malvolio's sanity will be measured by the answers he gives - thus incidentally echoing Malvolio's previous declaration that anyone who disagrees with his notion of persons, place, and time must be mad. Yet Feste hijacks the form of the catechism when he declares even Malvolio's most orthodox answers to be heretical. When Malvolio says he disapproves of Pythagoras, Feste says, "Fare thee well. Remain thou still in darkness. Thou shalt hold th'opinion of Pythagoras ere I will allow of thy wits" (4.2.56-58). The absurdity of a priest bullying someone into adopting pagan doctrines signals that the doctrines themselves are not at stake. When Malvolio complains about the darkness in his prison, Feste proclaims with similar absurdity that he is wrong about this too: the prison, he explains, "hath bay-windows transparent as barricadoes, and the clerestories [another type of window] . . . are as lustrous as ebony" (4.2.36-38). In reality, of course, neither barricades nor ebony let very much light through. The cruel genius of Feste's style is to declare any opinions Malvolio expresses to contradict a generally agreed upon consensus, of which he, Feste, has made himself the sole arbiter.

Like Olivia, Feste seizes on the importance of clergy in legitimating generally agreed upon truths. In disguising himself as a priest, he represents himself as the persons of the persons, place, and time triad — a fact Sir Toby's repeated references to him as "Master Parson" emphasize $(4.2 .11,27)$. Yet unlike Olivia, Feste makes a joke out of these persons' or parsons' relationship to consensus. He reduces it to absurdity, for example, in a story about an old hermit who "said to a niece of King Gorboduc, 'That that is is'; so I being Master Parson am Master Parson, for what is 'that' but 'that' and 'is' but 'is'?" (4.2.14-16). The multiple tautological claims in Feste's speech dramatize one of the weaknesses of consensus, which so often exists only insofar as someone invokes it. The absurdity of what Feste declares everybody agrees with-that dark is light, that barricades and ebony are transparent, and that all good Christians are Pythagoreans - takes the concept's shortcomings to the extreme. To paraphrase Laclau and Mouffe, consensus always has an outside. ${ }^{79}$ Yet here Malvolio is not even excluded because other 
characters share anti-Puritan preferences. I mentioned above that Feste does echo real-life anti-Puritans in calling Malvolio's speech "bibble babble," but his doctrinal flexibility suggests that Puritanism per se is not his target. ${ }^{80}$ Malvolio's exclusion is even more arbitrary than antiPuritan animus. His adversaries, it seems, simply dislike him and have agreed to share whatever preferences he does not. One can take Feste either to be embracing the most tyrannical tendencies of consensus politics or to be performing them ironically and thus exposing them to critique. In either case, his style is distinct.

My own purpose is not to valorize any of these particular styles of consensus, but to suggest, with Shakespeare, that debates about consensus politics might give more consideration to style as such. Style, as construed here, is the difference between imposing one's notion of persons, place, and time (Malvolio) and waiting for the place and time to work out while forgetting to specify the persons (Viola and Orsino). It is the difference between calling the priest or parson (Olivia) and pretending to be the priest or parson (Feste). All of the above characters appeal to a variation of what everybody would, could, or should agree with. Incorporating them into its own ambivalent promise of "what you will," Twelfth Night signals recognition that such variations could easily continue ad infinitum. This is style too. By presenting multiple different iterations of consensus, the play highlights the imperfection and provisionality of all of them. Intellectually, this approach grasps something profound about consensus, which itself—like style-exists only in multiple, provisional approximations.

To run with Barthes's metaphor, consensus is an onion too. Although it is easy to recognize Malvolio's appeal to generally agreed upon quiet hours as false, one could sort through all the oniony alternatives proposed in the play without finding the genuinely collective will promised in the subtitle. In nonetheless making such a promise, however, the play highlights something that too often gets lost in theoretical debates about consensus.

\section{STYLE'S UPSHOT}

Twelfth Night's understanding of consensus's onion-like nature is primarily descriptive, but it also offers a plausible model for how one ought to talk about consensus and deliberative politics - the politics I have been calling Habermasian as a shorthand. Deliberative theory can easily seem like a lost cause. Warren (whom I introduced briefly above) contends that we should bracket its entire project, because 
it has failed even after so many decades to balance the competing demands of inclusion and collective will formation (or in other words the pursuit of consensus). My own article bears out Warren's diagnosis, insofar as impasses emerging independently in modern and early modern debates about consensus are likely endemic to the concept. Yet I remain hesitant about his prescription. Based on a version of social-scientific functionalism, his "problem-based approach" privileges political outcomes over other goals, such as interrogating the reasons for pursuing those outcomes, which for him are ultimately matters of "common sense." 1

Shakespeare's style-based approach to consensus politics makes for an intriguing contrast Even as Twelfth Night devolves into parodic imitations of its theoretical sources, it shows no apparent interest in bracketing them. As I have highlighted, the play engages both with the problems occupying Stoughton, Fenner, and Hooker and with the semantics of such writers' arguments. Its assessment of their conceptual coherence may be critical, but its many citations and echoes of their prose leave the impression that it revels in the language of theory despite-even perhaps because of - theory's shortcomings. For one, it represents a richly textured way of doing political theory. Twelfth Night's nuanced attention to people's linguistic tics in talking about consensus foregrounds affect and historicity in a way more philosophically oriented approaches often do not. Yet it also implies a philosophical conclusion of its own.

In cheerfully reiterating phrases from debates that in real life were plainly going nowhere, the play signals that the debates are worth having even when participants are talking past each other. Twelfth Night's valuation of consensus is paradoxical. It retains its orientation toward collective will, while also emphasizing the elusiveness of this ideal and the hollowness of any thinkable approximation. Malvolio's last words promise to return for additional repetitions of the whole thing-to take revenge for the revenge his adversaries took on him for his initial appeal to consensus. The play's implicit contention, on this reading, is that the sprawling disagreements spawned by the initial promise of consensus will continue, and that apparent resolutions are never final. Insofar as the play has any investment in its subtitle, one can also infer a suggestion that the disagreements ought to continue, because this is the only condition under which the perpetually unfulfilled promise of what you will would have any meaning.

Whether Shakespeare's style-oriented approach to consensus is right for our world would of course be a separate question. Yet it seems 
plausible in light of two things this article has shown: that the history of consensus politics is long and sincerely argued even as its terms never quite add up. One functionalist response to such impasses is to bracket the theory and get to work. I disagree. The notion that a given society might be able to agree on real-life approximations of commonsense political ideals has been sufficiently dismantled by critics from Malvolio to Mouffe. The elusiveness of consensus may be particularly acute in the metadebates pursued by theorists, but there is no reason to believe that bracketing those would reveal a common agenda for political practice. Even if they did nothing but remind of that fact, theoretical debates would serve a purpose.

Thinking further in this direction, greater attention to style could energize deliberative theory. One eminently practical function of consensus is actually tied to the dysfunction of theoretical arguments about it, which seems bottomless considering the nearly 450 years of repetitions with relatively minor variations discussed in this article. Precisely because its terms never quite add up, deliberative theory keeps people with different notions of consensus talking to each other-even (based on some of the examples above) when nobody's promises of what you will are particularly valid and everybody some days sounds more like a variation on Elizabethan Puritanism than they would probably willingly admit.

\section{Bilkent University (Ankara)}

\section{NOTES}

I thank the many friends and colleagues who have talked with me about these ideas or read a draft, especially my dear friend Joseph Mansky (who read two); all of the participants in Allison Deutermann's fantastic 2018 SAA seminar, "Publicity and the Early Modern Stage"; and an anonymous reviewer at ELH who recognized what I was trying to do and taught me to understand it better. I also gratefully acknowledge two institutions: the Folger Shakespeare Library, which awarded me a Bess and Philip Rosenblum Short-Term Fellowship that made much of the research possible, as well as my home institution, Bilkent University.

${ }^{1}$ William Shakespeare, Twelfth Night, or, What You Will, ed. Keir Elam (London: Cengage Learning, 2008), 5.1.376-77. Hereafter cited parenthetically by act, scene, and line number. On the etymology of consensus, see OED, s.v. consensus, n., etymology.

${ }^{2}$ Brian Walsh, Unsettled Toleration: Religious Difference on the Shakespearean Stage (Oxford: Oxford Univ. Press, 2016), 87.

${ }^{3}$ See Roland Barthes, "Style and its Image," trans. Seymour Chatman, in Literary Style: a Symposium, ed. Seymour Chatman (London: Oxford Univ. Press, 1971), 3-10. Style can also mean other things, but Carlo Ginzburg makes the intriguing observation that some of its meanings are in fact virtual opposites of one another. See "Style as Inclusion, Style as Exclusion," in Picturing Science, Producing Art, ed. Caroline A. Jones and Peter Galison (London: Routledge, 1998), 27-54. 
${ }^{4}$ Habermasians are also known as deliberative democrats. For versions of their theoretical framework, see Jürgen Habermas, Theorie des Kommunikativen Handelns 2 vol. (Frankfurt a. M.: Suhrkamp, 1981); Nancy Fraser "Rethinking the Public Sphere: A Contribution to the Critique of Actually Existing Democracy," in Habermas and the Public Sphere, ed. Craig Calhoun (Cambridge: The MIT Press, 1992), 109-42; Maeve Cooke, "Habermas and Consensus," European Journal of Philosophy 1.3 (1993): 247-67; Seyla Benhabib, "Deliberative Rationality and Models of Democratic Legitimacy," Constellations 1.1 (1994): 26-52; Habermas, The Inclusion of the Other, ed. Ciaran Cronin and Pablo de Greiff (Cambridge: MIT Press, 1998); and John Dryzek, "Rhetoric in Democracy: A Systemic Appreciation,” Political Theory 38.3 (2010): 319-39.

${ }^{5}$ See Walsh 86-128; Jeffrey Knapp, Shakespeare's Tribe: Church, Nation, and Theater in Renaissance England (Chicago: Univ. of Chicago Press, 2002); and Jeffrey S. Doty, Shakespeare, Popularity and the Public Sphere (Cambridge: Cambridge Univ. Press, 2017).

${ }^{6}$ See Oliver Arnold, The Third Citizen: Shakespeare's Theater and the Early Modern House of Commons (Baltimore: Johns Hopkins Univ. Press, 2007).

${ }^{7}$ C. L. Barber, Shakespeare's Festive Comedy: A Study of Dramatic Form and its Relation to Social Custom, (Princeton: Princeton Univ. Press, 2011), 7. Barber discusses Twelfth Night specifically on pages 272-96.

${ }^{8}$ See Donna Hamilton, Shakespeare and the Politics of Protestant England (Lexington: Univ. of Kentucky Press, 1992); and Walsh, 86-110.

${ }^{9}$ See Valerie Traub, Desire and Anxiety: Circulations of Sexuality in Shakespearean Drama (New York: Routledge, 1992), 136-38.

${ }^{10}$ See James Bednarz, Shakespeare and the Poets' War (New York: Columbia Univ. Press, 2001), 105-32.

${ }^{11} O E D$, s.v. will, v. ${ }^{2}, 7,3$.a. Also, see $O E D$, s.v. will, v. ${ }^{1}, 1 . d, 2$ and will $v .^{2}, 2$. b.

${ }^{12}$ OED s.v. will, n. ${ }^{1}, 7$. b. See also OED s.v. will, $n .{ }^{1}, 1$. a, 5.b.

${ }^{13}$ William Stoughton, An Abstract of Certain Acts of Parliament (London: Robert Waldegrave, 1583, 60.

${ }^{14}$ See Walsh, 87,110 .

${ }^{15}$ Bednarz, 191.

${ }^{16}$ See Ernesto Laclau and Chantal Mouffe, "Preface to the Second Edition," Hegemony and Socialist Strategy: Towards a Radical Democratic Politics (London: Verso, 2001), vii-xix.

${ }^{17}$ See Walsh, 86-128.

${ }^{18}$ J. L. Simmons, "A Source for Shakespeare's Malvolio: The Elizabethan Controversy with the Puritans," Huntington Library Quarterly 36.3 (1973): 189.

${ }^{19}$ See Patrick Collinson, "A Comment: Concerning the Name Puritan," Journal of Ecclesiastical History 31.4 (1980): 483-88; and Lori Anne Ferrell, Government By Polemic: James I, the King's Preachers, and the Rhetorics of Conformity, 1603-1625 (Stanford: Stanford Univ. Press, 1998).

${ }^{20}$ See Patrick Collinson, "Ben Jonson's Bartholomew Fair: the Theatre Constructs Puritanism," in The Theatrical City: Culture, Theatre, and Politics in London, 1576-1649, ed. David L. Smith, Richard Strier, and David Bevington (Cambridge: Cambridge Univ. Press, 1995), 157-69, 167.

${ }^{21}$ See Simmons, "Shakespeare's Malvolio," 181-82; Phebe Jensen, Religion and Revelry in Shakespeare's Festive World (Cambridge: Cambridge Univ. Press, 2009), 149-93.

${ }^{22}$ See Hamilton, Shakespeare and the Politics of Protestant England, 86-110. 
${ }^{23}$ See Knapp, 174-76.

${ }^{24}$ Paul Yachnin, "Reversals of Fortune: Shakespeare, Middleton, and the Puritans," ELH 70.3 (2003): 781.

${ }^{25}$ See Walsh, 87, 100-106.

${ }^{26}$ See Simmons, "Shakespeare’s Malvolio," 190-91, 92.

${ }^{27}$ See Thomas Kranidas, "Malvolio on Decorum," Shakespeare Quarterly 15.4 (1964): 450-51; and Bednarz, 25-26, 192.

${ }^{28} \mathrm{John}$ Whitgift, An answere to a certen libel intituled, An admonition to the Parliament (London: Humfrey Toy, 1572), 233.

${ }^{29}$ Thomas Cartwright, The second replie of Thomas Cartwright: agaynst Maister Doctor Whitgiftes second answer, touching the Churche discipline (Heidelberg: Michael Schirat, 1575), 65.

${ }^{30}$ Richard Cosin, An answer to the two fyrst and principall treatises of a certaine factious libell, put foorth latelie . . . vnder the title of An abstract of certeine acts of Parlement (London: Thomas Chard, 1584), 259.

${ }^{31}$ Richard Harvey, A Theologicall Discourse of the Lamb of God and His Enemies (London: William Ponsonby, 1590), 5.

${ }^{32}$ George Gifford, A plaine declaration that our Brownists be full Donatists (London: Toby Cooke, 1590), 110.

${ }^{33}$ Richard Hooker, Of the Lawes of Ecclesiastical Polity. The Fift Booke (London: John Windet, 1597), 53.

${ }^{34}$ Hooker, Lawes. The Fift Booke, 137.

${ }^{35}$ Henry Barrow, A Plaine Refutation of M. G. Giffardes Reprochful booke (1591), 248-49.

${ }^{36}$ Dudley Fenner, A Counter-Poison, modestly written for the time, to make aunswere to the obiections and reproches, wherewith the aunswerer to the Abstract would disgrace the holy Discipline of Christ (London: Robert Waldegrave, 1584), sig. B2v.

${ }^{37}$ Andrew Willet, A Christian Letter of Certaine English Protestants . . . unto that Reverend and learned man, Mr R. Hoo. (Middleburg: Richard Schilders, 1599), 32.

${ }^{38}$ See Walsh, 92-113; Knapp, 174-76.

${ }^{39}$ See the variety of spellings in the sample citations provided in OED, s.v. parson, n., 1.a.

${ }^{40}$ See Peter Lake, Anglicans and Puritans? Presbyterianism and English Conformist Thought from Whitgift to Hooker (London: Unwin Hyman, 1988), 63-64.

${ }^{41}$ See Peter Lake and Michael Questier, The Antichrist's Lewd Hat: Protestants, Papists, and Players in Post-Reformation England (New Haven: Yale Univ. Press, 2002), 309; and Anthony Milton, "The Church of England, Rome and the true Church: the demise of a Jacobean consensus," in The Early Stuart Church, 1603-1642, ed. Kenneth Fincham (Basingstoke: Macmillan, 1993), 203. For one discussion of slightly later attempts to express the concept (though not the word), see Joanna Picciotto, Labors of Innocence in Early Modern England (Cambridge: Harvard Univ. Press), 201-2.

${ }^{42} \mathrm{On}$ the continuing relevance of (essentially) Roman-Catholic canons in Reformation England, see R. H. Helmholz, Roman Canon Law in Reformation England (Cambridge: Cambridge Univ. Press, 1990), 28-54.

${ }^{43}$ I quote the apocryphal Fourth Council of Carthage, because this is what Fenner cites: Concilia Africae, A. 345-A. 525, ed. C. Munier (Turnhout: Brepols, 1974), 343. See Fenner, 30.

${ }^{44}$ See John F. McDiarmid, "Common Consent, Latinitas, and the "Monarchical Republic' in mid-Tudor Humanism," in The Monarchical Republic of Early Modern 
England: Essays in Response to Patrick Collinson, ed. McDiarmid (Aldershot: Ashgate, 2007), 55-74; and Alan Cromartie, "Common Law, Counsel and Consent in Fortescue's Political Theory," in Political Culture in Late Medieval Britain, ed. Linda Clark and Christine Carpenter (Woodbridge: Boydell, 2004), 45-68.

${ }^{45}$ On publication details, see the English Short Title Catalogue: estc.bl.uk.

${ }^{46}$ Stoughton, 103.

${ }^{47}$ Stoughton, 60.

${ }^{48}$ See $O E D$, "consensus, n.," 2 , whose citations begin much later.

${ }^{49}$ Cosin, 91, emphasis added.

${ }^{50}$ See Habermas, "Vorwort zur Neuauflage 1990," in Strukturwandel der Öffentlichkeit: Untersuchungen zu einer Kategorie der bürgerlichen Gesellschaft (Frankfurt a. M.: Suhrkamp Verlag, 1990), 33.

${ }^{51}$ Habermas, Theorie des Kommunikativen Handelns, 2:126, my translation. See also Habermas, Inclusion of the Other, 239-52, which frames the argument in the terminology of lifeworld rather than of public sphere.

${ }^{52}$ On the early modern public sphere, see Doty; Joseph Mansky, “Unlawfully Published': Libels and the Public Sphere in Titus Andronicus," Shakespeare Quarterly 67.3 (2016): 293-318; and András Kiséry, Hamlet's Moment: Drama and Political Knowledge in Early Modern England (Oxford: Oxford Univ. Press, 2016).

${ }^{53}$ Ciaran Cronin and Pablo de Greiff, "Editors' Introduction," in Habermas, The Inclusion of the Other, $\mathrm{x}$, emphasis added.

${ }^{54}$ Benhabib, 33, emphasis added.

${ }^{55}$ Stoughton, 60.

${ }^{56}$ Habermas, "Three Normative Models of Democracy," in The Inclusion of the Other, 252.

${ }^{57}$ See Bernard Manin, "On Legitimacy and Political Deliberation," trans. Elly Stein and Jane Mansbridge, Political Theory 15.3 (1987): 338-68; and Habermas, Inclusion of the Other, 239-52.

${ }^{58}$ See Fraser, "Rethinking the Public Sphere," 119; and Benhabib, 39.

${ }^{59}$ Nancy Fraser, "Transnationalizing the Public Sphere: On the Legitimacy and Efficacy of Public Opinion in a Post-Westphalian World," Theory, Culture, and Society 24.4 (2007): 7. See also Fraser, "Rethinking the Public Sphere."

${ }^{60}$ See Chantal Mouffe, "Deliberative Democracy or Agonistic Pluralism," (Vienna: Institute for Advanced Studies, 2000); and Mouffe, "For an Agonistic Public Sphere," in Radical Democracy: Politics Between Abundance and Lack, ed. Lars Tønder and Lasse Thomassen (Manchester: Manchester Univ. Press, 2005).

${ }^{61}$ See Habermas, Theorie des Kommunikativen Handelns, 2:118-69.

${ }^{62}$ See Jürgen Habermas, "Religion in the Public Sphere," European Journal of Philosophy 14, no. 1 (2006): 1-25. Compare Dryzek, "Rhetoric in Democracy," 319-39. ${ }^{63}$ See Victoria Kahn, The Future of Illusion: Political Theology and Early Modern Texts (Chicago: Univ. of Chicago Press, 2014), 1-3.

${ }^{64}$ Mark E. Warren, "A Problem-Based Approach to Democratic Theory," American Political Science Review 111.1 (2017): 39, 42.

${ }^{65}$ See Fenner, 16-48.

${ }^{66}$ Cosin, 91 .

${ }^{67}$ Cosin, 101.

${ }^{68}$ Fenner, 25.

${ }^{69}$ Fenner, 28.

${ }^{70}$ Fenner, 25. 
${ }^{71}$ Fenner, 29.

${ }^{72}$ See Lake, Anglicans and Puritans, 145, 225-30.

${ }^{73}$ See Henry Turner, The Corporate Commonwealth: Pluralism and Political Fictions in England, 1516-1651 (Chicago: Univ. of Chicago Press), esp. 59-82.

${ }^{74}$ Richard Hooker, Of the Laws of Ecclesiastical Polity: Preface, Book I, Book VIII, ed. Arthur Stephen McGrade (Cambridge: Cambridge Univ. Press, 1989), 93.

${ }^{75}$ Hooker, Laws, 32.

${ }^{76}$ See Barthes, 9-10.

${ }^{77}$ On Hooker's repetitions, see Lake, Anglicans and Puritans, 225-30.

${ }^{78}$ See Elam's gloss in Twelfth Night, 351 .

${ }^{79}$ See Laclau and Mouffe, xviii.

${ }^{80}$ Twelfth Night, 4.2.97; see Simmons, "Shakespeare’s Malvolio," 190-91.

${ }^{81}$ Warren, 39, 43. 